\title{
Artikel
}

\section{Over stromen, waterscheidingen en koudwatervrees: de overgang van strafrecht naar GGZ sinds de Wet forensische zorg}

\author{
Prof.dr.mr. M.J.F. (Michiel) van der Wolf, mr. A.W.T. (Astrid) Klappe en prof.mr. P.A.M. (Paul) Mevis*
}

\section{Inleiding: risicomanagement als watermanagement}

De Wet forensische zorg (Wfz) is gefaseerd in werking getreden per 1 januari 2019 respectievelijk 2020. Het deel dat begin dit jaar in werking trad betreft vooral de mogelijkheid voor de strafrechter om op basis van artikel 2:3 Wfz een zorgmachtiging af te geven. Tegelijkertijd traden de civiele zorgwetten Wet verplichte GGZ (Wvggz) en Wet zorg en dwang (Wzd), als opvolgers van de Wet bijzonder opnemingen in psychiatrische ziekenhuizen (Bopz), in werking.

Op artikel 2.3 na bestaat de Wfz voor een groot deel uit de codificatie van bestaand beleid dat sinds 2008 is ingezet. In 2010 werd het Wetsvoorstel Forensische Zorg ingediend naast invoering van een Interimbesluit Forensische Zorg, waarin een overkoepelend systeem wordt gecreëerd voor zorg in strafrechtelijk kader. ${ }^{1}$ De Wfz is wel gekarakteriseerd als een organisatiewet, ${ }^{2}$ omdat het vooral regels bevat met betrekking tot de instellingen die

* $\quad$ Michiel van der Wolf is hoogleraar forensische psychiatrie aan het Instituut voor Strafrecht en Criminologie van de Universiteit Leiden en universitair hoofddocent strafrecht aan de Universiteit Groningen. Astrid Klappe is stafjurist strafrecht bij het Landelijk Bureau Vakinhoud rechtspraak. Paul Mevis is hoogleraar straf(proces)recht aan de Erasmus Universiteit Rotterdam.

1. Kamerstukken // 2009/10, 32398, nr. 2 en Interimbesluit Forensische Zorg (Stb. 2010, 875)

2. P.A.M. Mevis, A.W.T. Klappe \& M.J.F. van der Wolf, 'Wet forensische zorg: doelen, middelen en verwachte knelpunten', TVGR 2019, afl. 5, als aanbieder van die zorg voor een contract in aanmerking willen komen, regels over inkoop en financiering, indicatie en plaatsing. De belangrijkste doelen waren en zijn: de juiste patiënt op de juiste plek qua zorgbehoefte en beveiligingsnoodzaak te krijgen (maatwerk leveren), het creëren van voldoende forensische zorgcapaciteit, kwalitatief goede zorg gericht op de veiligheid van de samenleving en een goede aansluiting tussen de forensische en de curatieve zorg. ${ }^{3}$

Al deze formuleringen sluiten an bij de doelstellingen die er op dat moment (voor 2010) waren ten aanzien van de tbs-sector, waarin tot ongeveer die tijd - de populatie zou voor het eerst slinken in 2009 - sprake was van een capaciteitstekort. Vanaf halverwege de jaren negentig is er dan ook veel gesproken over instroom, doorstroom en uitstroom, die laatste twee toch vooral richting de GGZ. Met name het tweede Interdepartementaal Beleidsonderzoek (IBO-II), dat als titel met een dubbele betekenis 'Over stromen' had, ${ }^{4}$ verbond de thematiek van de overgang van Justitieel naar GGZ-kader nadrukkelijk met woorden die men eerder in de waterhuishouding verwacht, alsof het hier geen risicomanagement maar watermanagement betreft. Omdat ook andere aan water gerelateerde terminologie regelmatig opduikt in dit verband, met name de vermeende 'koudwatervrees' bij de GGZ ten anzien van forensische patiënten, ${ }^{5}$ en

p. 360 en J. Legemaate e.a., Thematische wetsevaluatie Gedwongen zorg, Den Haag: ZonMW 2014, p. 153.

3. Kamerstukken I/ 2009/10, 32398, nr. 3, p. 3-6.

4. Werkgroep IBO-II, Over stromen: In-, door-en uitstroom bij de tbs, Den Haag: Ministerie van Justitie 1998.

5. Zie bijvoorbeeld M.J.F. van der Wolf, TBS - veroordeeld tot vooroordeel. Een visie na analyse van historische fundamenten van recente 
vanwege de complexiteit van de materie kan dergelijke beeldspraak wellicht helpen voor een goed begrip. Daarom menen wij daar in deze bijdrage voort te borduren op deze voorlopige evaluatie van de gevolgen van de invoering van de wet ten aanzien van dit doel van doorstroom van strafrecht naar GGZ. In paragraaf 2 richten we ons daarbij op de beleidswijziging vanaf 2008, het inkopen van zorg door Justitie, en in paragraaf 3 op artikel 2.3 Wfz en de wederwaardigheden daarvan sedert het begin van dit jaar.

\section{Forensische zorg als overkoepelend beleidsterrein: verlegging van de waterscheiding ${ }^{6}$}

Volgens Van Dale is een waterscheiding in letterlijke zin 'een grenslijn tussen twee stroomgebieden', met name van hoofdrivieren die in zee uitkomen. Wat de analogie van het strafrecht en de GGZ als twee van zulke rivieren bruikbaar maakt, is het kenmerk dat tussen dergelijke rivieren (bijna) geen uitwisseling van water kan plaatsvinden: langs twee gescheiden (water)wegen stromen mensen die in maatschappelijke zin kopje onder zijn gegaan, terug de samenleving in.

Het beleidsonderzoek IBO-II zocht in 1998 de oplossingen voor de doorstroom vanuit de tbs in het creëren van zorgcircuits van forensische en reguliere GGZ-voorzieningen, in een plaatsingssystematiek en in een financiële prikkel. Vooral de eerste van deze vermeende oplossingen heeft het landschap blijvend veranderd, de tweede werd teruggedraaid voordat er enig effect van kon worden beoordeeld, ${ }^{7}$ en de laatste zorgde vooral voor doorstroom richting tbs-longstay-afdelingen die ongeveer rond dezelfde tijd in het leven werden geroepen. ${ }^{8}$ Er valt wel uit af te leiden dat de dammen niet gelegen waren in wettelijke onmogelijkheden - er werd in regelgeving al in genoeg overplaatsingsmogelijkheden voorzien - maar eerder in beleidsmatige belemmerin-

knelpunten, het systeem en buitenlandse alternatieven (diss. Rotterdam), Nijmegen: Wolf legal publishers 2012, p. 107 en 372.

6. Stukken uit deze paragraaf zijn ontleend aan M.J.F. van der Wolf, J. Reef \& A.C. Wams, Wie zijn geschiedenis niet kent... Een overzichtelijke tijdlijn van de stelselwijzigingen in de forensische zorg sinds 1988, Den Haag: Textcetera 2020.

7. De zogenaamde aselecte plaatsing, die bedoeld was om kliniekpopulaties vergelijkbaar te krijgen zodat er ook op prestaties afgerekend kon worden. Door de parlementaire onderzoekscommissie Visser werd dit teruggedraaid vanwege de voordelen voor de kwaliteit van zorg van differentiatie en specialisatie: Commissie-Visser, Tbs, vandaag over gisteren en morgen, Den Haag: Sdu 2006.

8. De zogenaamde outputfinanciering, waarbij een kliniek na zes jaar minder geld kreeg voor een patiënt. Doordat dit samenviel met een zesjaarscriterium voor plaatsing op de longstay (twee maal drie), had dit een aanzuigende werking. Zie B.C.M. Raes, 'Uren, dagen, maanden, jaren. Een essay over de TBS-longstay als deel van het geheel', in: B.F. Keulen e.a. (red.) Pet af. Liber Amicorum D.H. de Jong, Nijmegen: Wolf Legal Publishers 2007, p. 387398. gen. Een belangrijke belemmering was dat de verdeling van verantwoordelijkheid en financiering ten aanzien van de tbs niet gelijk verdeeld was tussen de departementen van Justitie en Volksgezondheid. Tachtig procent van de financiering kwam vanuit de AWBZ, terwijl Justitie juist het leeuwendeel van de verantwoordelijkheid droeg. De volgende commissie die zich over dit vraagstuk boog - de Commissie-Kosto - zou in 2001 bepleiten de tbs in de GGZ te integreren en zo Volksgezondheid ook echt meer zeggenschap te geven om de verantwoordelijkheidsverdeling in overeenstemming te brengen met de financiële verdeling. ${ }^{9}$ Dat laatste werd uiteindelijk verwezenlijkt, vanwege hetzelfde achterliggende doel van doorstroom naar de GGZ, maar dan in diametraal tegenovergestelde richting: Justitie zou alles gaan betalen (en dus ook alles bepalen?).

Deze financiële beleidsverandering - zowel qua budgetverdeling als qua systematiek - hield meteen ook een verbreding van het perspectief in waarin de tbs minder centraal stond. De motie-Van de Beeten uit 2004, waarin verzocht werd om 'noodzakelijke samenhang tussen curatieve en penitentiaire voorzieningen', geldt als startschot voor deze ontwikkeling naar een overkoepelend perspectief op zorg in justitieel kader, maar had een achtergrond in de toename van personen met psychische problematiek in detentie. ${ }^{10}$ De CommissieHoutman, die als gevolg daarvan werd geinstalleerd, rapporteerde in mei 2005 over hoe de aansluiting tussen het strafrecht en de GGZ te verbeteren om continuiteit van zorg te waarborgen. ${ }^{11}$ Voor de zorg in justitieel kader moest een inkoopmodel ingevoerd worden vanuit de begroting van het Ministerie van Justitie.

Kort na het rapport van de Commissie-Houtman, te weten in juni 2005, recidiveerde tbs-gestelde Wilhelm S., na een week eerder ontsnapt te zijn aan zijn begeleiders op station Utrecht Centraal. Hij beging een geruchtmakend levensdelict in Amsterdam. Het was de directe aanleiding voor het parlementair onderzoek naar het tbs-stelsel door de Commissie-Visser. Deze parlementaire onderzoekscommissie adviseerde veel veiligheidsmaatregelen voor de tenuitvoerlegging van de tbs, zoals de invoering van een Adviescollege Verloftoetsing (AVT). Ten aanzien van de financiering sloot de commissie geheel aan bij de aanbevelingen van de Commissie-Houtman. ${ }^{12}$

Op 1 januari 2008 begon de inkoopsystematiek van Justitie, een paradoxaal systeem van marktwerking met een monopolie voor de inkoper dat de financiering van de forensische zorg erg complex heeft gemaakt, doordat niet langer werd gefinancierd op basis van plaats, maar op basis van prestaties aan de hand van Diagnose

9. Commissie-Kosto, Veilig en wel: Een beleidsvisie op de tbs, Den Haag: Ministerie van Justitie 2001.

10. Kamerstukken / 2003/04, 28979, nr. E.

11. Commissie-Houtman, Advies Interdepartementale werkgroep Besturing en financiering van zorg in justitieel kader, Den Haag: Ministerie van Justitie 2005

12. Commissie-Visser 2006, a.w 
Behandeling en Beveiliging Combinaties (DBBC's), aansluitend bij de systematiek van de algemene gezondheidszorg. Het plan van aanpak naar aanleiding van de motie-Van de Beeten werd Project Vernieuwing Forensische Zorg genoemd, de term forensische zorg werd toen voor het eerst als overkoepelend beleidsterrein gebruikt. ${ }^{13}$ Tekenend voor de verbreding van de forensische zorg was de bijbehorende naamsverandering van de onderafdeling van de Dienst Justitiële Inrichtingen, genaamd Sectordirectie TBS, naar Directie Forensische Zorg (DForZo), een naamsverandering die ook aansloot bij die van het Ministerie van Justitie in dat van Veiligheid en Justitie. Omdat, zoals gezegd, de Wfz grotendeels de codificatie is van dit beleid van inkoop door Justitie, is een evaluatie van de Wfz in feite vooral een evaluatie van deze beleidskeuze uit het midden van het eerste decennium van deze eeuw.

In het eerste voorstel voor een $\mathrm{Wfz}$ werden negentien forensische zorgtitels onderscheiden: strafrechtelijke kaders waarbinnen zorg mogelijk is. ${ }^{14}$ Dat zijn er thans bijna dertig, waaronder vooral veel voorwaardelijke kaders, zoals de schorsing van de voorlopige hechtenis en voorwaardelijke invrijheidstelling, al staan die titels niet meer opgesomd in de wet zelf omdat ze elders zijn voorzien en vallen onder de later toegevoegde definitie van forensische zorg in artikel 1 lid $2 \mathrm{Wfz} .{ }^{15}$

Forensische zorg wordt ten uitvoer gelegd in forensische zorginstellingen, waaronder naast de Penitentiair Psychiatrische Centra in het gevangeniswezen en de Forensisch Psychiatrische Centra (FPC, beveiligingsniveau 4) voor tbs-gestelden vooral veel instellingen in de forensische GGZ (zoals Forensisch Psychiatrische Klinieken, FPK beveiligingsniveau 3, en Forensisch Psychiatrische Afdelingen in algemene psychiatrische ziekenhuizen, FPA beveiligingsniveau 2) en in de verslavingszorg, en alle (andere) instellingen die aan de eisen voldoen en een contract sluiten voor een aantal plaatsen met Justitie. Waar, na de maatregelen naar aanleiding van de Commissie-Visser, de tbs minder populair werd, groeide de populatie van de 'overige forensische zorg', blijkend ook uit een grotere capaciteit in FPK's en FPA's. Als verklaring daarvoor is wel gegeven de ontsluiting van dit aanbod via het inkoopmodel. ${ }^{16}$ Veel van de betreffende zorgaanbieders leverden wellicht voor die tijd ook al zorg aan deze doelgroep, maar nog niet onder de - voorheen nog niet bestaande vlag van forensische zorg. Dit is dus geen reëel effect, maar is slechts het anders 'labelen' van bestaande zorg, en (vervolgens) een registratie-effect. Ook zijn er aanwijzingen dat de gegroeide instroom samenhangt met het succes van de forensische zorg in de zin van recidivevermindering. ${ }^{17}$ Mede op basis van dat succes zijn er andere beleidswijzigingen geweest - zoals 'GGZ, tenzij' ten aanzien van zorg in detentie - die ook weer een aanzuigende werking hadden op de forensische GGZ. ${ }^{18}$

Toch is het nog enigszins speculatief om deze groei geheel toe te schrijven aan de beleidsverandering. Er zijn daarvoor immers ook andere verklaringen te bedenken. Die gestegen instroom kan namelijk ook samenhangen met een reële toename van de doelgroep, bijvoorbeeld door ontwikkelingen in de samenleving en de reguliere GGZ, versobering van maatschappelijke voorzieningen, ambulantisering en (verhoging van de) eigen bijdrage. Hierdoor zou het risico groter geworden kunnen zijn dat mensen in de 'criminaliteit' belanden en met multiproblematiek de strafrechtsketen instromen, te beginnen bij de grondslag waarop de politie optreedt 'op straat': in het kader van de strafvordering of ter openbare ordehandhaving. Al is het - net als bij het aantal meldingen bij de politie van verwarde personen, dat sinds 2011 alleen maar stijgt - ook mogelijk dat dit komt door een afnemende maatschappelijke tolerantie voor verward gedrag en verondersteld gevaar. ${ }^{19}$ Ten slotte kan - net als eerder in de tbs - ook een stagnerende uitstroom uit de forensische GGZ een deel van de groeiende capaciteitsbehoefte verklaren. Zo is gewezen op de beperkte mogelijkheden voor doorstroom naar zelfstandig of begeleid wonen en een veranderd beeld onder de professionals van wanneer iemand kan doorstromen naar een lager beveiligingsniveau of klaar is om toe te werken naar resocialisatie en te starten met verlof. De forensische zorgtrajecten zouden hierdoor langer (kunnen) zijn geworden, mede onder invloed van de beeldvorming na incidenten. Juist die stagnerende uitstroom uit de forensische GGZ heeft weer een effect gehad op bijvoorbeeld de groei van het aantal Regionale Instellingen voor Beschermd Wonen (RIBW's) als forensische zorgaanbieder. Ook de capaciteit in de forensische GGZ blijft, zij het in mindere mate, doorgroeien. Daarbij kan het argument van het fungeren als alternatief voor de tbs minder opgeld doen, nu sinds het 'Michael P.-effect' de tbs-populatie vanaf 2019 ook weer stijgt. $^{20}$ Zijn geval - te gevaarlijke patiënt in een FPA is een van de aanwijzingen dat er naast een kwantitatieve, ook een kwalitatieve verschuiving heeft plaatsgevon-
13. Het eerste moment waarop wij het gebruik van deze term zijn tegengekomen ligt overigens al in 1997, en wel in de titel van het rapport: Interdepartementale Werkgroep Kaasjager, Forensische Zorg, het gevangeniswezen en de geestelijke gezondheidszorg, Den Haag: Ministerie van Justitie 1997

14. Kamerstukken // 2009/10, 32398, nr. 2

15. Zie www.forensischezorg.nl/introductie/keten-forensische-zorg/foren sische-zorgtitels. Al is thans nog die informatie verouderd, nu art. $37 \mathrm{Sr}$ er nog bijstaat.

16. Dat kwam ook als verklaring naar voren uit de expertsessies van een onderzoek naar deze groei.
17. Zie C.L. van der Vis, S. Struijk \& M.J.F. van der Wolf, 'Recidivecijfers na forensische zorg: een juridische "proof of the pudding"', Ars Aequi 2020, afl. 4, p. 321-330.

18. Zie bijv. Significant, Vraagontwikkeling OFZ: Onderzoek naar de oorzaken van de stijging naar de vraag van Overige Forensische Zorg, 2014 en Andersson Elffers Felix, Forensische zorgen; Onderzoek naar de kwaliteit en veiligheid in de forensische zorg, 14 mei 2018.

19. Zie bijv.: B. Koekkoek, De kwestie verwarde personen. Naar een andere benadering van onbegrepen gedrag, Tielt: Lannoo Campus 2019.

20. 'Michael P-effect: Aantal tbs'ers neemt toe, maar niet genoeg capaciteit', Metro 15 juli 2020 
den van de tbs-populatie naar minder stevige omgevingen en forensische titels. ${ }^{21}$

Kortom, de waterscheiding tussen strafrecht en GGZ is niet geslecht, maar steeds verder verlegd. Het lijkt erop dat Justitie zich steeds verder in het nazorgtraject moet inkopen om doorstroom mogelijk te maken.

In het promotieonderzoek van Steinmann naar de gevolgen van de stelselwijziging in de forensische zorg sinds $2008,{ }^{22}$ is deze conclusie reeds te vinden: de doorstroom vanuit de tbs naar lagere beveiligingsniveaus is wel geholpen met de wijziging, maar juist voor de overige forensische zorg is de doorstroom richting reguliere GGZ - of de continuiteit van zorg - verslechterd. Het anders 'labelen' van bestaande zorg - in één categorie met tbs-gestelden nota bene - heeft volgens Steinmann die patiënten herkenbaarder gemaakt als forensische patiënten, met als gevolg dat GGZ en samenleving ze minder verwelkomen. Er lijkt ook wel enige evidentie voor die stelling in de toegenomen media-aandacht voor forensische patiënten die geen tbs-gestelde zijn. Zo was een ongeoorloofde afwezigheid van een niet-tbs-gestelde uit de FPA Den Dolder in de nasleep van de Anne Faber-zaak ook nieuws: ${ }^{23}$ een ander Michael P.-effect.

Met andere woorden: waar vroeger tbs werd gezien als de 'middenpositie' tussen strafrecht en GGZ, ${ }^{24}$ is nu eigenlijk de forensische GGZ in de middenpositie tussen het strafrecht (inclusief tbs) en de reguliere GGZ gedrongen. De grens wordt voor een belangrijk deel nog steeds gevormd door een overgang van financieringssystematiek. Dat blijkt ook uit de eerste ervaringen met de 'shortcut' uit de Wfz die een directe overgang van strafrecht naar reguliere GGZ mogelijk maakt: als een kanaal gegraven tussen beide stroomgebieden.

\section{De zorgmachtiging door de strafrechter: koudwatervrees en een kanaal met sluizen}

Koudwatervrees is volgens Van Dale in figuurlijke zin onnodige vrees. Vooral vanuit strafrechtelijk perspectief is de afwerende opstelling van de GGZ ten opzichte van forensische patiënten wel als zodanig getypeerd, waarbij in ieder geval sprake is van een verschil in visie over

21. Zie ook: Andersson Elffers Felix 2018, a.w. Er zijn wel aanwijzingen voor wie dan overgebleven zijn in de tbs aan het eind van de neergang van de populatie. RSJ, 'Langdurig in de tbs' Stagnatie in de door- en uitstroom van ter beschikking gestelden, Den Haag: 30 april 2020.

22. P.L.M. Steinmann, Stelselwijziging forensische zorg: Verklarend onderzoek naar een centralisatie van sturing in de zorg (diss. Twente), Universiteit Twente: 2019.

23. " "Gevaarlijke" patiënt ontsnapt uit forensische kliniek Den Dolder waar Michael P. verbleef', Volkskrant 5 juni 2019.

24. Zie Landelijke Beraad (Hoogst) Inhoudelijk Verantwoordelijken (2005), 'De terbeschikkingstelling in de middenpositie' (ongepubliceerde notitie van het Landelijke Beraad Inhoudelijk Verantwoordelijken van de forensisch-psychiatrische behandelcentra in Nederland 29 december 2005). 'openbare orde-' of publieke functie van de GGZ. Wellicht is deze opstelling van de GGZ wel hardnekkiger geworden doordat Justitie forensische zorg inkoopt en daarmee het signaal afgeeft die publieke functie binnen dat kader helemaal over te nemen.

Vanuit de GGZ wordt die vrees echter onderbouwd en wordt de mogelijkheid van artikel $2.3 \mathrm{Wfz}$ zelf juist - in de woorden van een geneesheer-directeur van een GGZ-instelling - als 'gevaarlijk en onnodig' beschouwd. Hij stelt dat de reguliere psychiatrie weinig kan met deze categorie patiënten. 'Het gedrag van deze doelgroep ontwricht het behandelklimaat en vormt een bedreiging voor medepatiënten en personeel. Daarnaast is recidivepreventie niet de focus van de reguliere behandeling en is toeleiding naar een vervolgvoorziening in zes maanden tijd eenvoudigweg niet te realiseren (...) Doorplaatsing naar een forensische instelling met een hoger beveiligingsniveau stuit op financiële obstakels.' $^{25}$

Een zelfde strekking had het artikel met de veelzeggende titel 'Behandel "boeven" buiten de reguliere psychiatrie' van een aantal geneesheer-directeuren in de Volkskrant. ${ }^{26}$ Daarin wordt gewezen op het inderdaad verwarrende gegeven dat artikel 2.3 weliswaar in de Wfz staat, maar het verlenen van een zorgmachtiging door de strafrechter op voet van dat artikel vervolgens, in de uitvoering van die machtiging zelf, geen forensische zorg is die betaald wordt door Justitie. ${ }^{27}$ Dat heeft in de praktijk de consequentie dat doorplaatsing naar een forensisch bed wettelijk wel mogelijk is, maar dan weer op een financieel obstakel stuit, nu forensische bedden zijn gecontracteerd door Justitie en dus bezet zijn door andere titels ofwel bewaard worden voor forensische patiënten, die ook financieel meer opleveren. ${ }^{28}$

In een eerste verkenning van de jurisprudentie ten aanzien van artikel $2.3 \mathrm{Wfz}$ - recent verschenen in de rechtspraakrubriek van Delikt en Delinkment - lieten wij zien dat niet alle strafrechters dit weten. ${ }^{29}$ De strafrechter heeft in voorkomende gevallen ook behoefte aan een (strafrechtelijke) maatregel, ${ }^{30}$ zoals de artikel $37 \mathrm{Sr}$ plaatsing de voor de strafrechter beschikbare maatregel

25. J. Schetters, Voorwoord 'Forensisch Psychiatrische Patiënten', Opportuun 2020, afl. 3. Aan hem ontlenen we ook de term 'shortcut'.

26. A. Visscher e.a., 'Behandel 'boeven' buiten de reguliere psychiatrie', Volkskrant 12 juli 2020.

27. Juridisch kan men ook wel beweren dat op basis van de definitie uit art. 1 lid $2 \mathrm{Wfz}$ forensische zorg ook verplichte zorg kan zijn - zie bijvoorbeeld C. Reijntjes-Wendenburg, Gedwongen psychiatrische zorg. Wet verplichte ggz \& Wet forensische zorg, Deventer: Wolters Kluwer 2020 - maar wij verstaan dat artikel als duidend op de inhoud van de zorg en niet het financieel beleidskarakter van die zorg.

28. Zorgverzekeraars hanteren, anders dan Justitie, (strengere) maximum vergoedingen, zie A. Visscher e.a. 2020, a.w.

29. A.W.T. Klappe, P.A.M. Mevis \& M.J.F. van der Wolf, 'Het afgeven van een zorgmachtiging door de strafrechter: overzicht en eerste indrukken van de praktijk betreffende art. 2:3 Wfz sedert 1 januari 2020', DD 2020/43, afl. 7, p. 584-623.

30. Ook in letterlijke zin is art. $2.3 \mathrm{Wfz}$ wel als zodanig geïnterpreteerd om bijvoorbeeld voorlopige hechtenis of een schadevergoeding voor de slachtoffers mogelijk te maken. Zie de voorbeelden in Klappe e.a., a.w. 
was voor ontoerekeningsvatbaren van artikel $39 \mathrm{Sr}$. Maar de voorziening van die maatregel in (art. 37 van) het Wetboek van Strafrecht is, met de komst van artikel 2.3 Wfz en op zichzelf systematisch terecht, komen te vervallen, om de overgang naar en opvang in de GGZ, in het bijzonder onder de Wvggz, te kunnen bewerkstelligen. ${ }^{31}$ Vóór 1 januari 2020 was het ook niet altijd eenvoudig om iemand geplaatst te krijgen, ${ }^{32}$ maar artikel 37 (oud) $\mathrm{Sr}$ was in ieder geval forensische zorg, zodat een plek op een FPK of FPA gemakkelijker te realiseren was. Er lag met de beslissing van de strafrechter bovendien een executoriale titel van deze rechter ten aanzien waarvan een executieplicht bestond, waardoor de strafrechter ook van plaatsing uit kon gaan. Niet voor niets 'gelaste' de strafrechter de plaatsing in een psychiatrisch ziekenhuis naar de tekst van artikel $37 \mathrm{Sr}$ (oud). In de huidige regelgeving van artikel $2.3 \mathrm{Wfz}$ blijft het verlenen van een zorgmachtiging (van een last is geen sprake meer) een naar materieel recht civielrechtelijke aangelegenheid, ook als die machtiging in een strafgeding door de strafrechter wordt verleend. In een artikel voorafgaand aan de invoering van artikel $2.3 \mathrm{Wfz}$ vroegen wij ons al af of de strafrechter en het door hem te hanteren (onderzoeks- en beslissings)systeem van strafvordering en van sanctionering uit het $\mathrm{WvSv}_{\mathrm{v}}$ en het $\mathrm{WvSr}_{\mathrm{v}}$ hiervoor wel geschikt zou zijn. ${ }^{33}$ In ieder geval loopt die strafrechter, overigens mede door onduidelijkheden en onvolkomenheden in de regelgeving, tegen zowel formele als materiële beperkingen aan, met - voor wie de jurisprudentie bekijkt - kennelijk enige frustratie.

De belangrijkste formele beperking is dat de strafrechter voor het kunnen afgeven van een zorgmachtiging in het kader van de afhandeling van een strafbaar feit door berechting afhankelijk is van de voorbereiding van en het verzoekschrift tot een zorgmachtiging van de officier van justitie, in diens civiele hoedanigheid als voorzien in de Wvggz. Dit, omdat het bepaalde in artikel 2.3 Wfz - de aan de (straf)rechter toegekende ambtshalve bevoegdheid om een zorgmachtiging af te geven slechts betekenis kan hebben als de rechter daarvoor ook beschikt over de onderliggende stukken. De officier van justitie is op zijn beurt weer afhankelijk van de medische verklaring en het zorgplan zoals de geneesheer-directeur die bij een onafhankelijke psychiater en de zorgverantwoordelijke ingevuld moet zien te krijgen. Extra complex daarbij zijn artikel 5:11 lid 2 en artikel 5:17 lid 1 Wvggz, ingevolge waarvan de OvJ verdere activiteiten ter voorbereiding van een zorgmachtiging achterwege heeft te laten, als hij meent dat niet aan de criteria voor het verzoeken van een zorgmachtiging voldaan is. De rechter, ook de strafrechter, kan - gelet op de letter van

31. Machtiging voor opname via de WZD is nog maar weinig voorgekomen, recentelijk wel tweemaal door rb. Amsterdam op 21 augustus 2020 (ECLI:NL:RBAMS:2020:4173) en 3 september 2020, ECLI:NL: RBAMS:2020:4359.

32. Zie M.J.F. van der Wolf, 'De beperkingen van de strafrechtelijke plaatsing in de GGZ (artikel 37 Sr)', Sancties 2017, p. 74-80. Men moest ook lang wachten in HvB of PPC op plaatsing. Art. $37 \mathrm{Sr}$ werd de laatste jaren gemiddeld zo'n tachtig keer per jaar opgelegd.

33. Mevis e.a. 2019, a.w., p. 367. de wet - niet meer doen dan de OvJ 'verzoeken' toepassing te geven aan de bepalingen tot voorbereiding van een zorgmachtiging: artikel 5:19 lid 2 Wvggz.

Ten tijde van artikel $37 \mathrm{Sr}$ had de strafrechter als formeel vereiste een multidisciplinair pro Justitia-rapport nodig, dat hij enerzijds zelf kon initiëren, maar waar hij inhoudelijk overigens van kon afwijken. In de artikel 2.3 $\mathrm{Wfz}$-zaken is een regierol weggelegd voor de officier van justitie. Dit roept de vraag op of de strafrechter zich nu, materieel het civiele recht van de Wvggz toepassend, meer lijdelijk zou moeten opstellen? ${ }^{34}$ In een aantal strafzaken ontstond daarop discussie over de mogelijkheid van ambtshalve toepassing van artikel $2.3 \mathrm{Wfz}$, het bepaalde in artikel 5:19 lid $2 \mathrm{Wvggz}$ en de civielrechtelijke rol van de OvJ als regievoerder in de Wvggz-procedure. Het arrest van het gerechtshof Arnhem-Leeuwarden (penitentiaire kamer) in een van dergelijke zaken, ${ }^{35}$ is door het OM voor cassatie in belang der wet voorgedragen aan de P-G bij de Hoge Raad. Dat initiatief illustreert het verschil in interpretatie. In die zaak beriep de OvJ zich op zijn positie op grond van de verhoudingen in de Wvggz, hetgeen de penitentiaire kamer in een overweging ten overvloede als 'niet passend' bestempelde. De gang van zaken toont hoezeer het $\mathrm{OM}$ zich in een moeilijke middenpositie bevindt tussen enerzijds de beginselen van het strafproces - de strafrechter, die zich volledig geinformeerd moet voelen, alvorens in staat te zijn de door de wetgever gewenste integrale afweging te kunnen maken tussen straf en zorg - en anderzijds de procedure als omschreven in de Wvggz, met een regietaak voor de geneesheer-directeur daar waar het de zorg en de plaatsing betreft. ${ }^{36}$

Aan de ene kant staat hier het OM dat in feite (mede vanuit de traditionele rol onder de Bopz) meer gewend is om te gaan met de nieuwe hybride structuur van het verlenen van de zorgmachtiging door de strafrechter, dan de strafrechter gewend was te doen onder artikel 37 Sr. ${ }^{37}$ Uit de wetgeving blijkt ook dat bij ambtshalve toepassing van artikel 2:3 Wfz door de strafrechter, het OM nog steeds alle eigen beslismomenten moet doorlopen (art. 5:19 lid1 en 2 jo. art. 5:11 en art. 5:17

34. Wij wijzen hierbij ook op een 'ambtshalve' mogelijkheid uit de Wvggz, uit art. 6:4 lid 2; indien de rechter van oordeel is dat aan de criteria voor verplichte zorg is voldaan, maar met de in het zorgplan of de medische verklaring opgenomen zorg het ernstig nadeel niet kan worden weggenomen, kan hij in de zorgmachtiging in afwijking van het zorgplan andere verplichte zorg of doelen van verplichte zorg opnemen, alsmede in de zorgmachtiging bepalen dat een ander zorgplan moet worden opgesteld.

35. Hof Arnhem-Leeuwarden 23 april 2020, ECLI:NL:GHARL:2020:3335. Zie ook twee beslissingen van rb. Amsterdam van 9 juli 2020, ECLI:NL:RBAMS:2020:3342 respectievelijk ECLI:NL:RBAMS:2020:3342.

36. Wij spraken in dat kader in onze eerdere publicatie over de 'weigerachtige OvJ', bedoeld als een auteursknipoog naar de 'weigerachtige observandus'. Onze formulering was geenszins bedoeld om afbreuk te doen aan de moeilijke, niet goed doordachte positie waarin de wetgever het $\mathrm{OM}$ hier kennelijk brengt.

37. De discussie bestaat langs dezelfde lijnen ook op het scheiden van stukken tussen de procedures, zie bijvoorbeeld rb. Zeeland-West-Brabant 28 mei 2020, ECLI:NL:RBZWB:2020:2328, waarin onder protest de medische verklaring door het $\mathrm{OM}$ is verstrekt. 
Wvggz). Aan de andere kant staat de strafrechter die zich niet afhankelijk en beperkt wil zien in de afdoening(smogelijkheden) van een strafzaak in zijn geheel, met een zorgmachtiging als een onderdeel daarvan, een afdoening waar die rechter een volledige en eigen (ambtshalve) verantwoordelijkheid voor draagt. Hem wordt gevraagd om in de afdoening van de zaak een integrale afweging te maken tussen alle, in de concrete zaak beschikbare straf- en zorgmodaliteiten (inclusief combinaties daarvan). Daarbij past juist geen rechterlijke lijdelijkheid. De strafrechter kan ook een opgelegde straf niet meer aanpassen als blijkt dat een verleende zorgmachtiging niet wordt uitgevoerd; van enige zekerheid daarover zou hij idealiter bij zijn beslissing wel moeten kunnen uitgaan, maar gegarandeerd is dat - zo blijkt thans uit de praktijk - niet.

Het is te begrijpen dat beide actoren (rechter en OM) hun positie met argumenten gebaseerd op andere routes in de nog niet uitgekristalliseerde regelgeving beargumenteren. Het $\mathrm{OM}$ richt zich daarbij wellicht meer op de letter van de wet, en de strafrechter op de (gemiste) systematiek. In zoverre is het vooral niet voldoende doordachte wetgeving die de partijen zo tegenover elkaar heeft gezet. Het is goed dat de Hoge Raad zich hierover spoedig zal kunnen uitspreken. Niet uit te sluiten valt dat daarna dan toch de wetgever weer aan zet zal zijn, want bij de huidige stand van de wetgeving is het uiteraard sowieso de vraag of de strafrechter met enig 'afdwingen' iets wint, nu dit uiteindelijk slechts kan leiden tot niet meer dan een machtiging (zoals gezegd: geen 'last' meer, zoals in art. $37 \mathrm{Sr}$ (oud)) aan de GGZ om de zorg ten uitvoer te leggen. De GGZ zal in dergelijke gevallen, waarin men dus in feite al heeft laten weten op een dergelijke machtiging geen prijs te stellen, de zorg(machtiging) allicht niet executeren.

Om in onze beeldspraak te blijven: artikel $2.3 \mathrm{Wfz}$ is een kanaal tussen de stroomgebieden van het strafrecht en de GGZ met verschillende sluizen. Het is daarbij echter niet de strafrechter die sluiswachter is bij de laatste sluis richting de GGZ. Dat is de geneesheer-directeur (zelf). Het 'koude' water uit het strafrecht kan in deze constellatie buiten het stroomgebied gehouden worden om het water van de GGZ op temperatuur te houden. Aan de justitiabele die an GGZ-zorg en behandeling behoefte en aanspraak heeft, kan daarmee dan wel gemakkelijk tekort worden gedaan; die valt zo tussen wal en schip.

De vraag of in materiële zin de situatie voor de strafrechter nu heel anders is dan onder artikel $37 \mathrm{Sr}$ (oud), is al vaker beantwoord. Recent door Van Oploo, Prinsen en Bakkum, die nog eens de verschillen op een rij zetten. ${ }^{38}$ In een eerder artikel schreven wij dat artikel $37 \mathrm{Sr}$ door artikel $2.3 \mathrm{Wfz}$ is 'geabsorbeerd'. ${ }^{39}$ Daarmee bedoelen wij vooral dat artikel $2.3 \mathrm{Wfz}$ niet de vervanger

38. L.E. van Oploo, M.M. Prinsen \& Th.J.G. Bakkum, 'De invoering van artikel 2.3 Wet forensische zorg - Consequenties voor de strafrechtspraktijk', NJB 2020/2166, afl. 32, p. 2385-2386.

39. Mevis e.a. 2019, a.w., p. 363. van artikel $37 \mathrm{Sr}$ is, omdat het nieuwe artikel een veel groter toepassingsbereik heeft. Zo was toepassing van artikel $37 \mathrm{Sr}$ alleen mogelijk jegens een tijdens de berechting als volledig ontoerekeningsvatbaar beschouwde justitiabele; artikel $37 \mathrm{Sr}$ was verbonden aan de betreffende schulduitsluitingsgrond van artikel $39 \mathrm{Sr}$. De inzet/toepassing van artikel $2.3 \mathrm{Wfz}$ is daarentegen mogelijk op elk moment in het strafproces - eventueel op afzonderlijke vordering van het $\mathrm{OM}$ - en naast de einduitspraken van vrijspraak, ontslag van alle rechtsvervolging of het opleggen van enige sanctie. Uit onze bovengenoemde, eerste verkenning van de rechtspraak bleek, dat er inderdaad reeds toepassing wordt gegeven aan deze nieuwe vormen en reikwijdte; vooral het verlenen van een zorgmachtiging naast het opleggen van een voorwaardelijke gevangenisstraf komt voor. ${ }^{40}$ De (strafrechtelijke) bijzondere voorwaarden functioneren dan om niet-zorggerelateerde zaken te kunnen adresseren en tegelijk ook als een nazorgmodaliteit na tenuitvoerlegging van de zorgmachtiging. Bij die uitspraken hebben wij echter nog wel een kanttekening nu dergelijke voorwaarden in het kader van voorwaardelijke modaliteiten alleen met instemming kunnen worden 'opgelegd', terwijl het bij de zorgmachtiging juist om dwang- of verplichte zorg gaat. In de betreffende uitspraken wordt in de motivering niet altijd helder waar betrokkene nu wel of niet mee instemt. De strafrechter denkt thans bij verplichte zorg vooral nog aan opname, terwijl wij ons ook goed kunnen voorstellen dat bij instemming met voorwaarden maar dreigende medicatie-ontrouw vooral (dwang bij) die medicatie gemachtigd wordt. Overigens heeft de Hoge Raad recent bepaald dat ook medicatie en opname samen gemachtigd kunnen worden, waarbij de opname dan voorwaardelijk is voor het geval de ambulante verplichte zorg niet volstaat. ${ }^{41}$ Daarbij is de mogelijkheid van het machtigen van enkel medicatie, zonder opname, een andere vergroting van het toepassingsbereik ten opzichte van art. 37 $\mathrm{Sr}$ (oud).

Vervolgens is interessant dat artikel $2.3 \mathrm{Wfz}$ al eens is toegepast bij beslissing tot schorsing van de voorlopige hechtenis, een volgende mogelijkheid die voorheen niet bestond. In de betreffende zaak is echter overwogen dat de gemachtigde opname tenuitvoergelegd moet worden op beveiligingsniveau 3 (FPK) of 4 (FPC). Voor een FPC is de mogelijkheid van een dergelijke plaatsing ook wettelijk geregeld omdat er dan sprake is van een andere regeling van de rechtspositie, namelijk via de Beginselenwet Verpleging Ter beschikking gestelden. ${ }^{42}$ Voor een FPK - waar qua rechtspositie de Wvggz geldt net als in de reguliere GGZ, al is er voor geplaatsten op een

40. Klappe e.a. 2020, a.w

41. HR 25 september 2020, ECLI:NL:HR:2020:1508. Zo wordt dus de voorwaardelijke machtiging zoals die bestond onder de Bopz, maar die verdwenen is in de Wvggz, in zekere zin weer tot leven gewekt. Dit - nota bene - op basis van de grondgedachte achter de Wvggz dat altijd voor de minst bezwarende vorm van zorg moet worden gekozen.

42. Art. 6:4 lid 3 (tijdelijke plaatsing) en lid 4 (definitieve plaatsing) Wvggz. Zie ook Van Oploo e.a. 2020, a.w., p. 2388, over de mogelijkheid van plaatsing in een PPC (dat ook beveiligingsniveau 4 heeft). 
strafrechtelijke titel dan hoofdstuk $9 \mathrm{Wvggz} \mathrm{-} \mathrm{is} \mathrm{zo'n}$ overweging over de plaats van de tenuitvoerlegging meer een overweging ten overvloede, omdat dit niet kan worden afgedwongen, temeer nu daar ook het geschetste financiële obstakel voor geldt dat in het begin van deze paragraaf is geschetst: die bedden zijn grotendeels ingekocht voor forensische zorg.

Naast de mogelijkheid van de tenuitvoerlegging van de zorgmachtiging in een FPC is er, ten opzichte van artikel $37 \mathrm{Sr}$ (oud) nog een 'veiligheidsmaatregel' in de Wvggz opgenomen voor degenen jegens wie door de strafrechter de zorgmachtiging is verleend. Dat is het vereiste uit artikel 8:18 lid 4 Wvggz dat voor het voortijdig beëindigen of tijdelijk onderbreken van de opname (dit geldt enkel bij opname) - wanneer betrokkene niet is vrijgesproken van hetgeen ten laste is gelegd in de connexe strafzaak - instemming nodig is van de Minister van Justitie en Veiligheid. In het conceptformat dat voor de beslissing over die toestemming is opgesteld, moet onder andere een risicotaxatie worden aangeleverd. De expertise om deze op te stellen ontbreekt binnen de reguliere psychiatrie. Zo verzucht een geneesheer-directeur: 'De opname uitzingen tot de machtiging verloopt en ondertussen de schade beperkt zien te houden is het enige wat resteert. ${ }^{43}$ Overigens is het maar de vraag of deze lijdelijke opstelling van de GGZ de enige juiste interpretatie van de regelgeving is. Wij vragen ons af in hoeverre het niet langer voldoen aan de materiële criteria voor een zorgmachtiging niet zwaarder zou kunnen wegen dan de toestemming van de minister.

Wellicht belangrijker is de vraag in hoeverre deze kenmerken van de nieuwe regeling ten behoeve van de veiligheid, opwegen tegen de kenmerken die daar afbreuk aan lijken te doen ten opzichte van artikel 37 (oud) Sr. Ten eerste noemen wij hier de kortere maximumduur van de zorgmachtiging van thans zes maanden, in plaats van een jaar onder de oude regeling. Dat verschil lijkt het verlenen van een machtiging vanuit het oogpunt van veiligheid onaantrekkelijker te maken. Daarbij moet wel worden aangetekend dat verlenging mogelijk is, alleen dan niet door de strafrechter maar door de civiele rechter. Aan de andere kant geldt, en gold ook vroeger al, dat het gaat om een maximumduur, waarbij de zorg ook eerder kan worden beëindigd. In de huidige situatie dan wel slechts met instemming van de minister.

Als tweede moet hier weer het gesignaleerde financiële obstakel, dat artikel 2.3 Wfz geen forensische zorg is, genoemd worden. Zo lijkt de situatie te ontstaan dat iemand ofwel in de reguliere psychiatrie ofwel afdwingbaar in een FPC wordt opgenomen, terwijl de tussenliggende faciliteiten van de forensische GGZ buiten bereik blijven, maar dit juist de faciliteiten zijn waar voorheen artikel 37 Sr-geplaatsten doorgaans verbleven; er valt wederom een groep justitiabelen tussen wal en schip. Eerder hebben wij daarom geprognosticeerd dat de oude artikel $37 \mathrm{Sr}$-doelgroep wellicht vaker in de zwaardere

43. Schetters 2020, a.w. tbs-maatregel terecht zou kunnen komen. ${ }^{44}$ Van Oploo, Prinsen en Bakkum gaan daar ook van uit, vooral ook op basis van het bovenstaande en een casusbeschrijving. ${ }^{45}$ Uit onze eerste verkenning van de jurisprudentie blijkt dat echter nog niet meteen, vooral ook omdat de gevallen van ontoerekeningsvatbaarheid zeer ernstige delicten betroffen, waar ook voorheen al vaker tbs werd opgelegd. Van Oploo et al noemen wel dat artikel 37 (oud) Sr sporadisch ook bij ernstige delicten werd toegepast, maar dat was eerder de uitzondering dan de regel. $\mathrm{Zij}$ menen echter dat er een deel van de oude doelgroep buiten het bereik van artikel $2.3 \mathrm{Wfz}$ blijft en dat als zodanig de artikel 37 Sr-doelgroep niet geheel wordt 'geabsorbeerd' door de nieuwe regeling, en voor hen tbs resteert.

De auteurs concluderen dat er twee oplossingen lijken te zijn: 'of de reguliere ggz moet snel en stevig intensiveren in meer beveiligde bedden (maar ook dan blijft de duur onder de schakelbepaling van artikel $2.3 \mathrm{Wfz}$ te beperkt), of deze verdachten zouden behandeld moeten worden in een (bij aanvang) forensisch kader. Gezien de huidige worsteling met deze belangrijke patiëntengroep, concluderen wij dat er met de invoering van artikel 2.3 $\mathrm{Wfz}$, naast een verrijking, tegelijkertijd een verschraling van de mogelijkheden heeft plaatsgevonden. ${ }^{46}$

De auteurs suggereren de wetgever daarom om een nieuwe strafrechtelijke maatregel te introduceren - naar

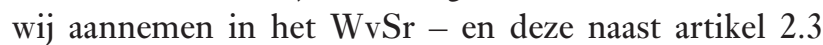
Wfz als mogelijkheid voor de strafrechter te laten bestaan. Hun gedachten gaan daarbij uit - onder verwijzing naar een advies van de Nederlandse Vereniging van Psychiatrie ten behoeve van reparatiewetgeving - naar een (strafrechtelijke) maatregel met een breder bereik dan alleen de ontoerekeningsvatbaren, waarbij toezicht op de tenuitvoerlegging wettelijk is vastgelegd en waarbij de duur van de maatregel één jaar betreft, met de mogelijkheid om te verlengen met een jaar. Maar daarna zal dan logischerwijs een zorgmachtiging (via art. 2.3 Wfz) nog mogelijk (moeten) zijn, zoals vroeger ook na artikel $37 \mathrm{Sr}$ (oud) de civiele rechter de opname kon verlengen. Zelf menen wij in onze rechtspraakrubriek dat herstel van een (zelfstandige) strafrechtelijke sanctie in het $\mathrm{WvSr}$ niet de oplossing zal zijn en ook niet hoeven te zijn. ${ }^{47}$ Waar het verlenen van een zorgmachtiging door de strafrechter wordt geregeld ( $\mathrm{WvSr} / \mathrm{WvSv}$ of $\mathrm{Wfz}$ ) is niet zo belangrijk, al moeten de consequenties van de huidige regeling in artikel $2.3 \mathrm{Wfz}$ voor onderdelen van het $\mathrm{WvSr}_{\mathrm{v}}$ en $\mathrm{W}_{\mathrm{vSv}}$, als gezegd, nog eens goed worden doordacht. Aan nog een aparte maatregel ergens tussen strafrecht en GGZ in, lijkt ook niet direct behoefte omdat in de huidige opzet al veel gewonnen zou zijn met de mogelijkheid artikel 2.3 Wfz onder

\footnotetext{
Mevis e.a. 2019, a.w., p. 359-373

Van Oploo, e.a. 2020, a.w., p. 2386-2388.

Van Oploo, e.a. 2020, a.w., p. 2390.

Klappe e.a. 2020, a.w.
} 
forensische zorg te scharen, ${ }^{48}$ zodat Justitie betaalt en plaatsing in de forensische GGZ (FPK of FPA) makkelijker mogelijk is. Dat vergt niet eens wetswijziging en zal heel wat weigerachtigheid en gesloten sluizen schelen. Een te overwegen aanvullende veiligheidsklep zou wat ons betreft zijn om de strafrechter de competentie te geven over de verlenging van zorgmachtigingen, verleend op voet van artikel $2.3 \mathrm{Wfz}$, te beslissen. Op die manier blijft ook na de eerste zes maanden de instemming van de Minister van Justitie en Veiligheid vereist voor beëindiging van de zorg. Een en ander zou dan ook moeten leiden tot een vermelding van de zorgmachtiging op de justitiële documentatie.

De door ons voorgestane weg lijkt voorts aangewezen om een forensische interpretatie van het gevaarscriterium te bewerkstelligen, ook bij verlenging van de machtiging. We hebben het namelijk tot nog toe vooral over de formele obstakels gehad, maar er valt tevens nog wel wat te debatteren over de materiële criteria op basis waarvan ook forensische patiënten buiten de deur van de GGZ worden gehouden. Zo wordt vaak geredeneerd dat er bij deze 'forensische klanten' geen vereiste relatie bestaat tussen ernstig nadeel - het gevaarscriterium uit de $W_{v g g z}$ - en stoornis. Uiteraard valt recidivegevaar onder ernstig nadeel, maar dan redeneert men dat het gevaar niet (geheel) voortvloeit uit de stoornis, maar bijvoorbeeld uit risicofactoren als gebrek aan dagbesteding en netwerk en dat dus in deze redenering niet aan de criteria van de GGZ voldaan is. Echter, zo kan men zich in veel gevallen afvragen, vloeien die risicofactoren dan niet voort uit de stoornis?

Een andere manier om op inhoudelijke grond de 'forensische klant' te weren is via het criterium dat de verplichte zorg doelmatig moet zijn. Zo wordt bijvoorbeeld antisociaal gedrag voortvloeiend uit een persoonlijkheidsstoornis niet gezien als iets dat doelmatig behandeld kan worden in de GGZ, zodat dat leidt tot beëindiging van de zorg.

Al doende past de praktijk zich hier niet aan de wet aan, maar wordt de wet verstaan vanuit de eigen cultuur. Voor een andere interpretatie is geen wetswijziging nodig, maar een - veel ingewikkeldere - cultuurverandering. Een cultuur van wat wel 'forensische scherpte' wordt genoemd en die in de forensische GGZ, vallend onder dezelfde wetgeving als de reguliere GGZ, inmiddels wel bestaat. Die cultuur kan wel veranderd worden, maar dat is dan afhankelijk van de facilitaire, financiële en rechtspositionele mogelijkheden. Meer beveiliging vraagt 'hogere hekken' en meer personeel, dus ook meer geld, en ook meer mogelijke inbreuken op rechten en vrijheden. Hier wordt vanuit de GGZ vaak tegenin gebracht dat 'de goeden niet onder de kwaden mogen lijden', maar nu die inbreuken door de rechter moeten

48. De Brief van de staatssecretaris van Volksgezondheid, Welzijn en Sport van 3 juli 2020 (Kamerstukken I/ 2019/20, 25424, nr. 548) wijst al meer in die richting - men wil dergelijke plaatsingen in de praktijk faciliteren. worden gemachtigd bestaat daartegen al een stevige waarborg, terwijl de geciteerde uitspraak geen afbreuk doet aan de noodzaak van en aanspraak op behandeling bij de 'kwaden'.

Met de door ons voorgestelde ingrepen wordt het systeem minder overhoop gehaald dan met toevoeging - dan wel herstel - van een strafrechtelijke maatregel. De vraag is bijvoorbeeld ook welke interne rechtspositie voor die groep aan wie zo'n nieuwe of herstelde maatregel kan worden opgelegd, zou (moeten) gelden. Het meest logisch zou zijn die van tbs-gestelden in de zin van hoofdstuk 9 van de Wvggz, maar dan worden degenen aan wie deze maatregel is opgelegd in zoverre voor wat de rechtspositie betreft, alsnog deels met die groep van tbs-gestelden gelijkgesteld. Dit punt steekt in zoverre dieper: de huidige regeling en overloop van rechtspositie zijn al erg onduidelijk. Het moet niet zo zijn dat met een nieuwe groep tot een nieuwe maatregel veroordeelden, dat veld van regeling van de rechtspositie nog onoverzichtelijker wordt.

\section{Slot: er moet nog heel wat water door de Rijn stromen}

Als we de Wfz beoordelen op het doel om doorstroom vanuit het strafrecht naar de GGZ te bevorderen, dan hebben wij in deze bijdrage vooral de stelselwijziging van de forensische zorg vanaf 2008 beschouwd - het inkoopmodel door de Minister van Justitie en Veiligheid zoals grotendeels gecodificeerd in de $\mathrm{Wfz}-$ en de directe overgangsmogelijkheid via de zorgmachtiging door de strafrechter. In de beeldspraak van het watermanagement is gebleken dat de stelselwijziging vooral de waterscheiding verlegd heeft. Was voorheen de overgang van tbs naar (forensische) GGZ ingewikkeld, thans zijn de plaatsing in en de overgang van forensische GGZ naar de reguliere GGZ of vervolgvoorzieningen (zoals beschermd wonen) vanwege de financiële barrière ingewikkeld. Die dam lijkt - in ieder geval vooralsnog - niet goed te doorbreken via artikel $2.3 \mathrm{Wfz}$, omdat financiële obstakels een negatief effect hebben op plaatsingen en de reguliere GGZ op basis van vrees voor onveilige situaties - de sluis gesloten houdt. Uiteindelijk blijft de overgang derhalve stuiten op financiële obstakels en culturele alsook rechtspositionele verschillen, al hebben we aan die laatste verschillen in deze bijdrage nauwelijks aandacht besteed. ${ }^{49}$ Die dam slechten blijft nog steeds de uitdaging. $\mathrm{Zo}$ is er voorzichtig alweer geopperd of niet een andere budgetverdeling met Volksgezondheid een optie is,${ }^{50}$ zodat ook dure zorg vanuit niet-forensisch kader kan worden bekostigd. Kortom, nu zijn eerst de Hoge Raad en de wetgever aan zet. Maar ook daarna moet er nog heel wat water door de Rijn stromen..${ }^{51}$

49. Zie Legemaate e.a. 2014 , a.w., p. 240-251.
50. Zie Steinmann 2019, a.w., p. 404-405.

51. Al prefereren wij de Maas. 